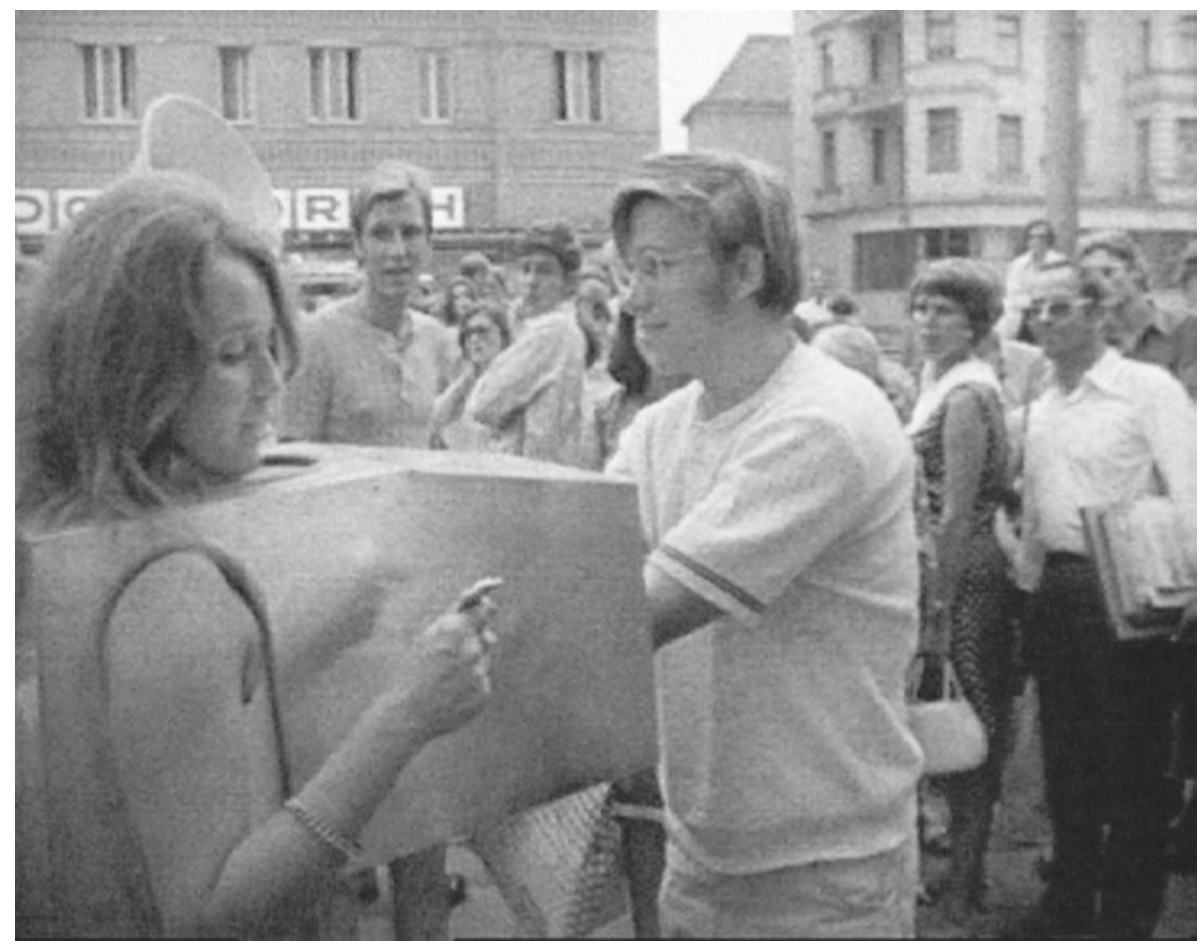

Fig. 6: Valie Export, Tapp und Tastkino (TAP and TOUCH Cinema), 1968/1989, video @ Valie Export / Museum of Modern Art, New York. 


\section{When to Touch and What to Doubt: Zeroing In on the Tactile Surplus}

\section{Touching as Doubting: Against the Visual Surplus}

Touching as an act of doubt begins when one ceases to believe one's eyes. Yet this does not imply that the tactile organs will be any more accurate than the eyes were. For Epicurus and Lucretius, the senses are always right, and no sense is entitled to criticise another. ${ }^{1}$ If, for them, touching possesses any superiority over vision at all, $^{2}$ this is due to vision's tendency towards totalisation and teleology-as, for example, expressed in the ancient Roman formula "videant consules (ne quid detrimenti res publica capiat)." ${ }^{3}$ Seeing seems to trigger the imagination, dragging it towards meaning, towards foreseeing and providence-that is, towards the Stoic gods. Touching, on the contrary, appears to perceive one's being pushed from behind by the meaningless collisions of atoms. ${ }^{4}$

If there is a sceptical power specific to touching, this power is not so much directed against the visual image, but against the mind's contribution to it-against one's imagination. Therefore, Lucretius emphasises that one should not blame the eyes for the mistakes of the mind. ${ }^{5}$ It is the mind that intervenes in seeing and makes it deceptive, while touching proves to be more robust and less susceptible to such interventions. ${ }^{6}$ Thus, touching affirms being against, for example, wishing,

1 See Lucretius, De rerum natura 4.490-500.

2 For this problem, see Jakob Moser, "Manifest gegen die Evidenz. Tastsinn und Gewissheit bei Lukrez," in Auf die Wirklichkeit zeigen. Zum Problem der Evidenz in den Kulturwissenschaften. Ein Reader, ed. Helmuth Lethen, Ludwig Jäger, and Albrecht Koschorke (Frankfurt: Campus, 2015), 98-99.

3 Literally translated, this means "the consuls shall see that the republic does not take any harm." 4 See, for example, Marcus Aurelius's concise formula "the atoms, or the Gods" (Selbstbetrachtungen, trans. Wilhelm Capelle [Stuttgart: Kröner, 1948], 107), which refers to the fact that the Stoic technique of consolation consisted in considering current inconvenience to have some higher meaning, whereas Epicurean consolation consisted in reducing it to meaningless atomic collisions (see Marcus Aurelius, Meditations 8.15, accessed 19/09/2018, http://www.gutenberg.org/files/2680/2680-h/2680h.htm\#link2H_4_0243).

5 Lucretius, De rerum natura 4.380-90.

6 However, this should not lead to the assumption that touching would only provide reliable "primary qualities," whereas seeing would, beyond questionable "secondary qualities," also imply notions of an external object. Also, touching allows for more than just sensations. For this, see the perspicuous remarks in Ernst H. Weber, Tastsinn und Gemeingefühl, ed. Ewald Hering (Leipzig: Wilhelm Engelmann, 1905) 6f., which analyses Gustav Fechner's examples of how one can feel the solidity of an external object like a table by pressing a pen against it. One then does not only feel a slight pain in one's finger, but also the quality of the table, even through a non-sensitive medium. We can feel ex- 
or hoping; it recalls what things are instead of what we want to see in them, or what we hope them to be or to become, or what we make out of them. It is significant that it is possible to speak of "what one wants to see in something," yet not of "what one wants to touch in something."

To put this in Aristotelian terms, one could say that seeing is the method of the "dialectician," who sees in the house the purpose of protection from wind, rain, and heat, whereas touching is the method of the "physicist," who describes a house as something composed of stones, bricks, and wood. ${ }^{7}$ Whereas the dialectician heads for the meaning of a thing, the physicist returns to its matter. Seeing concerns final causes; touching concerns material causes. The problem with the visual sense is that images are always mixed with imagination. This is the reason why blindness, already in Lucretius and later in Diderot, is a formula for a disillusioned attitude. ${ }^{8}$ Sight often finds it difficult to abstain from imputing an interpretation or a supposition of finality into what it sees. Seeing thus regularly produces a surplus. This was wittily observed by Friedrich Nietzsche when he stated:

People are much more artistic than they think. - In the middle of a lively conversation I will often see the other person's face expressing his thoughts (or the thoughts I attribute to him) with a degree of clarity and detail that far exceeds the power of my visual ability:-such subtlety of muscle movement and ocular expression must have come from my own imagination. In all likelihood the person had an entirely different expression, or none at all. ${ }^{9}$

If seeing regularly produces such a surplus beyond available facts, touching may help to shed this baggage. This follows the principle of philosophical materialism, as Louis Althusser formulated it, "Not to tell oneself any stories." our freedom, for example, can be such a story. What we regard as our freedom may just be a fabrication, a "screen idea" that prevents us from acknowledging the coincidences and meaningless collisions of atoms that actually caused our actions. By removing the visual surplus, touching lays bare the meaninglessness that seeing falsely turned into meaning. Now, discerning meaninglessness behind apparent meaning is comedy's key move. This may explain why only a writer and director of comedy could be attributed with the notion of the "Lubitsch touch."11

ternal objects even through extensions of our tactile organs, just as we can feel (phantom) pain through absent organs.

7 See Aristotle, De anima, trans. R.D. Hicks (Cambridge: Cambridge University Press, 1907), $8 \mathrm{f}$.

8 For this, see Moser, "Manifest gegen die Evidenz." A late echo of this idea may reverberate in Marcel Duchamp's choice of “The Blind Man” for the title of his journal.

9 Friedrich Nietzsche, Beyond Good and Evil: Prelude to a Philosophy of the Future, ed. Rolf-Peter Horstmann and Judith Norman, trans. Judith Norman (Cambridge: Cambridge University Press, 2002), 82.

10 "Ne pas se raconter d'histoire": Louis Althusser, L'avenir dure longtemps, suivi de Les faits, ed. Olivier Cooper and Yann Mulier Boutang, 2nd augmented ed. (Paris: STOCK/IMEC, 1994), 247.

11 For this term, see Billy Wilder's lovely explanation in “The Lubitsch Touch," presented at the AFI Harold Lloyd Master Seminar in 1976, accessed 20/08/2018, https://www.youtube.com/watch? 


\section{The Touch and Its Surplus: Comic Success}

Comedy often starts when things receive a little "push"; when, due to some unintended impulse, things cease to go their planned or predicted way. Comedy starts with an Epicurean "clinamen." 12 This is the case, for example, when a mechanical doll that is supposed to represent the bride at the staged marriage of a stubborn young bachelor is accidently knocked over and broken (in Lubitsch's 1919 Die Puppe) and when, therefore, a real young woman must represent the doll that was previously supposed to represent a real young woman. Comedy's typical push thus produces two outcomes: first, something different happens from what had been foreseen, and second, this different event ultimately proves to be much better than the foreseen one. Comedy's push creates undeserved success and unexpected happiness-surplus happiness, as it were.

Thus, also, touch, as it is proper to comedy, produces a surplus, yet an entirely different surplus from that pertaining to the visual sense. Whereas seeing's surplus rests in the foreseen, touching's surplus resides in the unforeseen. Significantly, and especially in Lubitsch, this deviation (and its surplus), caused by the "push," concerns planned marriages and would-be couples: a real woman may thus replace a doll, or a ménage à trois a couple (as in Design for Living, or, amounting even to a ménage à quatre, in To Be or Not to Be). There is always something that comically exceeds the heterosexual monogamous matrix. Lubitsch's touch seems to regularly create a kind of funny surplus love. ${ }^{13}$

Whereas a foreseen surplus of the sort produced by seeing attempts to pass unacknowledged, the unforeseen surplus of touching reliably sticks out. ${ }^{14}$ What seeing adds to visual facts always appears to already belong to the image and does not appear to alter it. In this way, as Walter Benjamin remarked, history as seen (i.e., made up) by its current ruling powers always appears to be "how things once were." 15

Touching's surplus, on the contrary, does not contribute to completing such an image. Instead, it adds itself as an obscene supplement to what could otherwise have

\footnotetext{
v=7jOVRKzwURY. For the comedy of materialism, see Robert Pfaller, "Materialism's Comedy," Bedeutung 1 (2008): 20-28, and Robert Pfaller, The Pleasure Principle in Culture: Illusions without Owners, trans. Lisa Rosenblatt with Charlotte Eckler and Camilla Nielsen (London: Verso, 2014), 166-69.

12 For this notion, see Epicurus, Letter to Herodotus 43, in Epicurus, Briefe, Sprüche, Werkfragmente: Griechisch/Deutsch, ed. and trans. Hans-Wolfgang Krautz (Stuttgart: Reclam, 2005), 10. See also Lucretius, De rerum natura 2.219; see Ernst A. Schmidt, Clinamen: Eine Studie zum dynamischen Atomismus der Antike (Heidelberg: Universitätsverlag Winter, 2007); Mladen Dolar, "Tyche, Clinamen, Den," Continental Philosophy Review 46, no. 2 (2013): 223-39.

13 For this, see Pfaller, The Pleasure Principle in Culture.

14 For this, see Alenka Zupančič's beautiful considerations on what she calls "the odd one in" as the basic structuring element of comedy (The Odd One In: On Comedy [Cambridge, MA: MIT Press, 2008]). 15 See Walter Benjamin, "Über den Begriff der Geschichte," in Gesammelte Schriften, Bd. 1/2: Abhandlungen, ed. Rolf Tiedemann and Hermann Schweppenhaüser (Frankfurt am Main: Suhrkamp, 1980), 691-704.
} 
passed as a consistent image. ${ }^{16}$ Such a surplus causes us to question whether things were really as they previously seemed to be. For example, the emergence of surplus value may question the apparent fairness of a contract between a worker and an employer. Similarly, in Heinrich Heine's witty formula, "love, truth, freedom, and shrimp soup,"17 the last element, as a strange, slightly obscene surplus, questions the whole meaning and seriousness of the sequence formed by the three previous elements. As can be seen again here, this sceptical power of the touch surplus-especially with regard to what was planned or foreseen-is often not without humour.

\section{Touch, and You Know}

If touching leads to knowledge, however, the knowing person still need not be the touching one. They can also be the touched one. When, in Sigmund Freud's early psychoanalytic treatments, patients found themselves unable to remember a given thing, a little "pressure" from the analyst's hand helped them to regain their memories. Touching apparently functioned here as a trigger for transference: apparently, it allows the object-namely, the analyst-to replace one's ego-ideal and thus relieves the censorship exerted by it.

Again, a funny little push sets things in motion. Yet it is anything but easy to tell who is supposed to believe in the efficacy of this astonishingly efficient touch from the analyst: can we seriously say that it is the analysand who believes that it works? Rather, here, the touch seems to escape any belief and any possible vision: "I do not see how this shall work" seems to be the formula that describes the efficiency at work here. It is probable that the touch only works here insofar as nobody believes in it. Both sides may secretly think the same thing, namely: "Perhaps you believe in this silly trick, but I don't.”

However, the scepticism at work in this situation is not limited to this mutual non-belief. By doing something in which neither agent believes, the analyst permits the analysand to think, "I am no longer responsible for what happens now." And this is precisely what permits something to happen. The analysand is then able to recall and relate his memories. Yet what he tells us, if this succeeds, is more than what he knows. As Freud remarks: "What we want to hear from our patient is not only what he

16 To put this in Jacques Lacan's terminology, one can say that seeing produces master-signifiers, whereas touching produces objets $a$.

17 Heinrich Heine, Ideen. Das Buch Le Grand, ed. Dierk Möller (Stuttgart: Reclam, 1972), 19. For a brilliant analysis of these kinds of paradoxical classifications, see Mladen Dolar, "Officers, Maids, and Chimneysweepers," in Sex and Nothing: Bridges from Psychoanalysis to Philosophy, ed. Alejandro Cerda-Rueda (London: Karnac, 2016), 19-36. 
knows and conceals from other people; he is to tell us too what he does not know." ${ }^{\text {" }} \mathrm{A}$ little touch thus again brings about an obscene surplus over acceptable knowledge; a surplus that puts this knowledge into question. We could call this a sceptical triumph, since a person now becomes able to tell us what he does not know.

\section{Touching What Is Not There}

Mark Tansey's painting “Doubting Thomas"-well chosen by Rachel Aumiller for the invitation to the conference that led to this anthology-as well as the Doubting Thomas episode in St. John's Gospel could be read in a way that leads to a surprising point: we touch not when our knowledge is doubtful or inconsistent, but rather when an object itself is inconsistent. What we touch is precisely the inconsistency of the object. We are mostly putting our finger into a hole. If touching assures us of anything at all, it thus assures us of a lack in the Other. (One could say, according to Jean Laplanche's general theory of seduction, that this is what we hope to find, since we try to "seduce" the other by creating a little dimple as an erogenous zone. ${ }^{19}$ )

It is difficult to tell, therefore, precisely what illusion St. Thomas wanted to dissipate by touching: That it was only an image of Jesus in front of him, and not a real person? A ghost? Or a Jesus lookalike, but lacking wounds? How did Thomas know that this was not just another, less seriously wounded man? And what truth did he find instead? A wounded God?

\section{Brought to Touch}

Valie Export's famous 1968 performance “Tapp- und Tastkino” is an almost uncanny reminder of Caravaggio's depiction of “The Incredulity of Saint Thomas” (1601-1602) - not only due to the striking similarity between the compositions of the famous photograph and the famous painting, but also in one specific aspect. Sceptics are here not only touching, but actually invited (Export) or even forced (Jesus) to touch some of the other's most delicate parts. This reverses the usual pattern of curiosity and desire according to which we (sometimes) dare to touch what interests us.

In both of these cases, touching therefore appears to be a quite dubious privilege. Entertainingly, Jesus explains to Thomas, "Because you have seen me, you have believed; blessed are those who have not seen and yet have believed" (John 20:29; emphasis mine). Export places a greater comparative emphasis on the tactile

18 Sigmund Freud, "An Outline of Psychoanalysis," in The Standard Edition of the Complete Psychological Works of Sigmund Freud, Volume 23 (1937-1939): Moses and Monotheism, An Outline of Psychoanalysis and Other Works, ed. James Strachey et al. (London: The Hogarth Press, 1964), 174.

19 See Jean Laplanche, Le primat de l'autre en psychanalyse: Travaux 1967-1992 (Paris: Flammarion, 1997). 
character of the event by not permitting the spectator to see at all, but only to touch. Whereas in the arts, as well as in practices such as belly dance or striptease, spectators are usually allowed to see, but not to touch, here, the opposite rule applies. Such a touch may appear quite uncanny, obscene, or almost traumatic to the touching person: not because some "naked truth" has entered, but because of the surplus of touch over (non-)seeing. Only due to this help from its visual accomplice does touching appear to gain the dignity of "touching the Real."

The crucial point here is the fact that the touchers are prompted to touch more than they want to touch, and/or more than they can see. Seeing here takes on the meaning of wanting to see, and perhaps also of wanting to touch. It thus opens up a logic of desire. Due to seeing, things acquire a place that is proper to them, and they may thus induce a curiosity to also touch them. We may haptically want to check whether they are really there, whether they really feel the way they look, and so on. Here, seeing seems to work like a library catalogue, whereas touching corresponds to the attempt to find out whether the book promised by the catalogue is really there. In its role as desire, seeing thus creates a kind of assurance: we can be sure that everything we may touch has its proper place; there is nothing unforeseen upon which we could stumble. Even if some things should turn out not to feel the way they looked, or if they should not be where we had thought we would see them, this is only a minor disappointment-they are then just lacking in their proper place, like a missing book in a library. If desire works as a defence, as Jacques Lacan pointed out, ${ }^{20}$ the same goes here for seeing. Seeing provides a kind of screen that is located between us and our experiences-an "a priori," or, in other words, a prejudice-preparing us for any possible experience by giving it the character of an expected experience. Even if it may not appear likely or probable that things actually are there, or that they actually are how they appear to be (or that one is really allowed to touch them), they are still expected in the sense that their visual place, their possibility, precedes their haptic actuality.

On the other hand, being forced to touch, or seduced to touch what one cannot see, thus takes on the character of an experience outside of its screen, just like a book in a library that is not listed in the catalogue. ${ }^{21}$ What one encounters, then, is something which is not foreseen as a possible experience, something for which one cannot be prepared. This matches Sigmund Freud's explanation of what renders

20 "Desire is a defence (défense), a prohibition (défense) against going beyond a certain limit in jouissance": Jaques Lacan, Écrits: A Selection, trans. Alan Sheridan (London: Tavistock, 1977), 322; see Dylan Evans, An Introductory Dictionary of Lacanian Psychoanalysis, repr. ed. (New York: Routledge, 1997), 34.

21 Uncanniness regularly arises as a kind of surplus. To illustrate this with an example from my personal experience: I once wanted to open a door for which I thought I had a key. However, the key turned out not to work in that the door. I did not have the key for that door: this was a minor disappointment. Yet the next moment brought an awareness of the fact that I now had a key without knowing what door it could open. This was rather uncanny. 
an experience traumatic. ${ }^{22}$ A traumatic experience always arises as a surplus beyond a given screen or pattern (or catalogue) of possible experiences; as something that has no proper place within a given system of possible places; something that was not just unexpected, but that was impossible to expect. Only under these conditions does the haptic experience take on the unpleasant dignity of unlimited enjoyment (jouissance) in the Lacanian sense. Touching what one could not see, or what one did not want to touch before one got to touch it, means encountering something without being protected by one's defensive screen of desire.

Yet the unpleasant, traumatic character of the unprepared touch only emerges when such a protective visual screen exists at all. In order to be struck (or touched, as it were) by an unprotected haptic impression, one has to have such a protective screen. For something to be outside of a screen, there must be a screen in the first place. ${ }^{23}$ As Denis Diderot concluded, for a blind person, the haptic experience of Saint Thomas, just like that of the unknown man with his hands in Valie Export's box, would not have been traumatic, obscene, or uncanny. Blind people cannot be struck by something outside a protective visual screen, because they do not have such a screen. This-questionable-assumption is the reason why Diderot could paradoxically present the blind man as a hero of enlightenment, because he appeared to be a person free from cultural prejudices and therefore free from any sense of obscenity. ${ }^{24}$ Children are other candidates for this structural position in philosophical reasoning. In this sense, Sigmund Freud pointed out that children are not susceptible to

22 See Sigmund Freud, "Beyond the Pleasure Principle," in The Standard Edition of the Complete Psychological Works of Sigmund Freud, Volume 18 (1920-1922): Beyond the Pleasure Principle, Group Psychology and Other Works, ed. James Strachey et al. (London: The Hogarth Press, 1955), 12. 23 The same goes, of course, for the fetishist in Freud's explanation: in order to experience the view of the female genitals as "traumatic," one has to be "prepared" by an infantile sexual theory that assumes the omnipresence of the penis. Only under such an a priori would the absence of a penis be classified as "castration." The "realist" attitude (which, in the fetishist splitting, separates itself from the "wishful" attitude) is one whose "reality" is outlined by an infantile sexual theory. See Sigmund Freud, "Fetishism," in The Standard Edition of the Complete Psychological Works of Sigmund Freud, Volume 21 (1927-1931): The Future of an Illusion, Civilization and Its Discontents and Other Works, ed. James Strachey et al. (London: The Hogarth Press, 1961).

24 See Denis Diderot, “The Letter on the Blind," in Diderot's Early Philosophical Works, ed. and trans. Margaret Jourdain (Chicago and London: The Open Court Publishing Company, 1916), 81: "Though living in an age when philosophy has rid us of a great number of prejudices, I do not think we shall ever arrive at such complete insensibility to the prerogatives of modesty as this blind man. Diogenes would not have been a philosopher in his account." Obviously, Diderot is not interested in the actual reality of blind people's perception here. Instead, he tries to conceive the blind man as an embodiment of the aspirations of enlightenment: freedom from moral and aesthetic prejudices. Diderot reflects on and concedes to the contemporary criticism of his "utopian" concept of blindness made by the blind lady Mélanie de Salginac, especially concerning his idea of blind people's alleged lack of pity, in his "Addition to the Letter on the Blind," in Diderot's Early Philosophical Works, 142-57. I am indebted here to José María Sánchez de León Serrano for his most inspiring comments on these passages in Diderot presented at the "A Touch of Doubt: On Haptic Scepticism" conference held in Hamburg on 27 March 2018. 
the experience of the uncanny. ${ }^{25}$ If one lacks a protective cultural shield of desire, then nothing appears as an unprotected intrusion of jouissance. In order to be struck defenceless, one has to have some defences. The obscene, the uncanny, and the undesired enjoyment thus reveal their dependency on a cultural a priori. These experiences do not come under the mere absence of a protective screen, but under its determinate lack. ${ }^{26}$ The prefixes "ob-" and "un-" in the notions of "obscene" and "uncanny" designate a "determinate negation": it is culture-or perhaps only certain cultures-that constructs certain screens or "scenes" and, by the same move, posits something as being outside this screen, as uncanny or obscene. These excluded entities are cultural "constructs"-yet in the precise sense that they are "constructed" as the determinate outside of cultural construction, as "non-objects" or Undinge of a specific culture.

This is the reason why materialist philosophers such as Ludwig Marcuse have insisted on the idea that there is actually no such thing as the obscene. ${ }^{27}$ By similar reasoning, ancient philosophers, especially those from the Cynic school, such as Diogenes of Sinope, Crates, and Hipparchia, attempted to demonstrate the disadvantages of cultural education, of a prioris and prejudices, such as (according to them), for example, the feeling of shame. Attempting to "learn from the dogs" from whom they took their name, ${ }^{28}$ the Cynics staged shameless "obscene" performances in public spaces by living, eating, and even making love in the streets of Athens. Thus, they wanted to convince people that their cultural formation was a superfluous defence that unnecessarily designated some human experiences as obscene; something without which these things could be experienced as entirely ordinary and lived more happily. The Cynics' scepticism consisted in methodical doubt regarding the necessity of cultural patterns that designate certain experiences as uncanny or obscene. The late heirs of these ancient sceptics are, in the twentieth century, performance artists like Valie Export-a reference that is even more explicit in her performance with Peter Weibel, "Aus der Mappe der Hundigkeit” ("From the Portfolio of Doggedness,” 1968), in which she dragged him through Vienna’s most elegant shopping street on a dog lead, than in "Tapp und Tastkino." 29 The appearances of the Rus-

25 See Sigmund Freud, “The Uncanny," in The Standard Edition of the Complete Psychological Works of Sigmund Freud, Volume 17 (1917-1919): An Infantile Neurosis and Other Works, ed. James Strachey et al. (London: The Hogarth Press, 1955), 250.

26 This is precisely why Lacan described anxiety as what occurs when the lack (i.e., the protective screen) is lacking (Le Séminaire, livre X: L'angoisse, 1962-63, ed. Jacques-Alain Miller [Paris: Seuil, 2004], 53).

27 See Ludwig Marcuse, Obszön: Geschichte einer Entrüstung (Zürich: Diogenes, 1984).

28 Kuōn is the Greek word for "dog”; kunikos thus literally means “doggish.” A beautiful account of this philosophical tradition is to be found in Georg Luck, ed. and trans., Die Weisheit der Hunde: Texte der antiken Kyniker in deutscher Übersetzung mit Erläuterungen (Stuttgart, Kröner: 1997).

29 See Valie Export and Peter Weibel, “Aus der Mappe der Hundigkeit”, accessed 31/08/2018, http:// peter-weibel.at/index.php?option=com_content\&view=article\&id=27\%3Aaus-der-mappe-der-hundig- 
sian performance artist Oleg Kulik as an (often quite angry) dog also belong to this philosophical tradition. ${ }^{30}$ The aggressive monkey-artist whose performance comprised an impressive part of the recent film The Square (directed by Ruben Östlund, 2017) can probably be counted as a fellow-traveller of this "animalistic" criticism of human culture by the ancient Cynics.

While the philosophical Cynics and their late followers in performance art raised doubts regarding cultural conventions and pointed towards the idea of a culture free of prejudices and constructions-a culture that would produce no feeling of shame, no uncanny or obscene outsides-Sigmund Freud did the opposite. Freud pessimistically doubted the possibility of such a "liberated" culture. It may be true that some cultures have found a more placable way of dealing with difficult matters such as sex than, for example, modern bourgeois Western culture. ${ }^{31}$ Yet this does not stem from the fact that these cultures have avoided excluding certain matters from their cultural "screen." Repression, as Freud suspects, is "organic"; 32 it comes as a consequence of the development and hierarchisation of partial drives during sexual development, and culture only "superstructures" this condition, thereby, as it were, innocently taking the guilt upon itself. Yet what some cultures achieve, as opposed to others, is a way of celebrating the "accursed shares"-a practice that allows for the ambivalent, sacred issues to be transformed into sublime ones. Other cultures, like ours, thatperhaps following a late 1968 spirit which naively declares such issues to be mere cultural constructs; that is, actually non-existent-avoid celebrating these things and see their most noble task to be subjecting them to "negative cults" of abstinence, inevitably transforming them into something appalling. Our former gods that we have ceased to celebrate thus turn into our most horrible demons, as Freud (referring to Heinrich Heine's novella "Gods in Exile") remarks. ${ }^{33}$

At this point, doubt could become a means for re-evaluating touch: Freud's scepticism could help a postmodern culture that is obsessed with harassment of all kinds to find its way back to practices by which not every touch must necessarily be expe-

keit-1968\&catid=2\%3Amixed-media\&lang=de\&Itemid=11 and http://foundation.generali.at/sammlung/artist/export-valiepeter-weibel/artwork/aus-der-mappe-der-hundigkeit-5.html\#.W4qV8i35zNM. 30 For this, see Anselm Wagner, "Der Künstler als Hund. Kynische Strategien der Körperkunst," Noema art journal 43 (1996): 52-60.

31 "The most striking distinction between the erotic life of antiquity and our own no doubt lies in the fact that the ancients laid the stress upon the instinct itself, whereas we emphasize its object. The ancients glorified the instinct and were prepared on its account to honour even an inferior object; while we despise the instinctual activity in itself, and find excuses for it only in the merits of the object": Sigmund Freud, "Three Essays on the Theory of Sexuality," in The Standard Edition of the Complete Psychological Works of Sigmund Freud, Volume 7 (1901-1905): A Case of Hysteria, Three Essays on Sexuality and Other Works, ed. James Strachey et al. (London: The Hogarth Press, 1953), 149 (footnote added in 1910).

32 Sigmund Freud, "Civilization and Its Discontents," in The Standard Edition of the Complete Psychological Works of Sigmund Freud, Volume 21, 100.

33 Freud, “The Uncanny,” $235 \mathrm{f}$. 
rienced as a nuisance. The practices of celebration turn excluded and forbidden things into obligatory, sublime ones. Whereas one may shamefully avoid touching anybody else in ordinary, profane life, in sacred situations, such as, for example, in ritual dances, it becomes an obligatory, joyful exercise. What contemporary culture sadly lacks is not more prohibitions, rules, and regulations for avoiding bodily or psychic contact, but the opposite, the art of temporarily suspending profane life in such a way that people know when to touch and how their contact can be experienced as sublime.

\section{Being Touched by What One Sees}

The opposition between seeing and touching in the sense of a screen and its offscreen transgression, as we just have encountered it, can also occur within the visual field itself. There can be elements within a picture that form a kind of surface, a plain, coherent meaningful order of visual signs, while some other elements stick out from-or rather pierce through-this surface, thus taking on a righteous tactile quality. In his book Camera Lucida, Roland Barthes coined the notions of studium and punctum for these two different sources of visual experience. The first element, the studium, can be described as a surface of expectable meanings:

The first, obviously, is an extent, it has the extension of a field, which I perceive quite familiarly as a consequence of my knowledge, my culture; this field [...] always refers to a classical body of information..$^{34}$

The punctum, on the contrary, opposes itself to this predictable field:

The second element will break (or punctuate) the studium. This time it is not I who seek it out (as I invest the field of the studium with my sovereign consciousness), it is this element which rises from the scene, shoots out of it like an arrow, and pierces me..$^{35}$

Even if Barthes, in his role as the observer, is now pierced by this element as though by a kind of arrow, as opposed to Doubting Thomas, who (forcedly) pierces his Lord's lance-wound, the shattering quality of the experience appears to be quite the same. Just like Saint Thomas, who ventures for the hole in the other, Barthes experiences the punctum in the picture as "a little hole."36 And the punctum is, for Barthes, just as for Thomas, a "wound”:

34 Roland Barthes, Camera Lucida: Reflections on Photography, trans. Richard Howard (New York: The Noonday Press, 1988), $25 \mathrm{f}$.

35 Barthes, 26.

36 Barthes, 27. 
And because the photographs I am speaking of are in effect punctuated, sometimes even speckled with these sensitive points; precisely, these marks, these wounds are so many points. ${ }^{37}$

In this constellation between studium and punctum, despite the fact that both belong to the visual field, the punctum takes on a tactile quality, with all the implications and consequences explained above: the punctum comes from outside the field of the visually expectable, as a "supplement," 38 as something slightly uncanny or obscene, something "disturbing" 39 ; it is, just like the more or less "forced" touches discussed above, an "involuntary feature"; ${ }^{40}$ it comes unexpectedly and shakes and shatters a given certainty of "knowledge" or "culture," thus assuming a sceptical power.

What Lucretius attributed to visual images in general-that they are material and are emitted from the objects just like smells-is, in Barthes's account, only true for a certain type of visual element: the punctum. The studium appears to remain calm, yet the punctum emerges from the picture. While one looks for what the studium contains with "sovereign consciousness," the punctum is not "sought out" by the observer, but rather strikes him. The punctum, as it were, actively attacks the observer; it "pricks" and "bruises" him ${ }^{41}$ and jumps into his eye, ${ }^{42}$ whereas the studium remains "inert":

Many photographs are, alas, inert under my gaze. But even among those which have some existence in my eyes, most provoke only a general and, so to speak, polite interest: they have no punctum in them: they please or displease me without pricking me: they are invested with no more than studium. The studium is the very wide field of unconcerned desire, of various interest, of inconsequential taste: I like/I don't like. The studium is of the order of liking, not of loving; it mobilizes a half desire, a demi-volition; it is the same sort of vague, slippery, irresponsible interest one takes in the people, the entertainments, the books, the clothes one finds "all right." ${ }^{43}$

The fact that the punctum appears to actively engage and strike the observer implies that the latter is unable to reach the picture through the moderating filters of his moral and political culture, as is the case with the studium:

Thousands of photographs consist of this field, and in these photographs I can, of course, take a kind of general interest, one that is even stirred sometimes, but in regard to them my emotion requires the rational intermediary of an ethical and political culture. What I feel about these photographs derives from an average affect, almost from a certain training. ${ }^{44}$

37 Barthes, 26.

38 "Le punctum: c'est un supplement": Roland Barthes, La chambre claire: Note sur la photographie (Paris: Cahiers du cinéma/Galimard/Seuil, 1996), 89.

39 Barthes, Camera Lucida, 27.

40 Barthes, 47.

41 Barthes, 27.

42 See Barthes, 43.

43 Barthes, 27.

44 Barthes, 26. 
The filtered experience of what the studium permits us to expect only creates a predictable medium amount of affect that is willfully expended. ${ }^{45}$ The unprotected encounter with the punctum, on the contrary, "touches" and "moves" the observer. ${ }^{46} \mathrm{He}$ is brought not just to "like," but to "love." 47 The punctum creates an unpredictable amount of affect, an unwilling expenditure.

To sum this up, it can be said that through the punctum, the observer is brought beyond what he knows (the filter of his "moral and political education"), beyond what he intentionally and willfully seeks and accepts, and beyond his usual economy of affect. The sceptical power of the punctum's touch thus does not only question what a person knows about an object; rather, it questions the very position of the subject.

It is at this point that scepticism acquires a new direction; a new goal or object. Doubting now does not only mean questioning some presumed knowledge about an object. Instead, it tackles the subject position; that is, the unacknowledged assumptions, education, and opinions of the person in question. The touching doubt is not about an a posteriori; it is about the a prioris. It does not check questionable knowledge in order to gain certainty; it questions certainty itself - the unquestioned assumptions that form the general coordinates within which every particular item of knowledge is located. Such a "touching" doubt concerns the "lived world" of the subject; that is, the set of unacknowledged and taken for granted presuppositions that invisibly function for us, just like water for the fish that swim in it, as nicely explained by David Foster Wallace. ${ }^{48}$ Being touched by a punctum means to be struck in one's pre-conscious world-view, in the way one wishfully places oneself within the world as it is experienced-that is, in the terms of Louis Althusser, one's ideology, ${ }^{49}$ or, in the terms of the ancient philosophers, one's "opinion" or doxa. The fact that not only knowledge, but also the lived certainty that surrounds one's knowledge (as well as one's error and ignorance) is attacked by the touching doubt of the punctum explains why this arouses such a high amount of affect: for it is, as ancient philosophers such as the Stoic philosopher Epictetus taught, not facts, but people's "opinions" that arouse their passions. ${ }^{50}$

45 Barthes, 28: “According to my will as spectator."

46 Barthes, 43.

47 Barthes, 27; see Barthes, 43: "This particular punctum arouses great sympathy in me, almost a kind of tenderness."

48 David Foster Wallace, "This Is Water," commencement speech delivered at Pomona College, California, accessed 18/09/2018, https://www.youtube.com/watch?v=8CrOL-ydFMI.

49 See Louis Althusser, On Ideology, trans. Ben Brewster, new ed. (New York: Verso, 2008).

50 Epictetus, Handbüchlein der Moral: Griechisch/Deutsch, ed. and trans. Kurt Steinmann (Stuttgart: Reclam, 2004) 10f. (§ 5); see also Epictetus, The Enchiridion, trans. Elizabeth Carter, accessed 19/09/ 2018, http://classics.mit.edu/Epictetus/epicench.html. 


\section{Affirmative and Transformative Doubting}

The history of philosophy features two prominent sceptical positions of relevance to this question that must be distinguished here. On the one hand, there is the modern, Cartesian doubt. This is a "cognitive" or "epistemological" doubt, whose aim is to establish certainty in the sense of reliable knowledge. This doubt only concerns objects of knowledge (the subject, on the contrary, is what is seen as beyond any doubt). On the other, we find the ancient Pyrrhonean scepticism (named after its founder, Pyrrho of Elis). This is an "ethical" scepticism. The aim of doubting here is not knowledge or certainty, but, on the contrary, "untroubledness" (ataraxia) by fixed ideas. Pyrrhonean doubt concerns the subject position. This scepticism does not care whether certain ideas are true or not, but only whether treating them as true may lead the subject into unpleasant excitement. Therefore, Michel de Montaigne, a late heir of this ancient tradition, would ask himself the question "What do I know?" whenever he found himself in a critical situation, an exercise by which he managed to abstain from any dogmatism or fanatic partisanship and to remain in a subject position of benevolent, serene curiosity.

Valie Export's touching performance obviously belongs to the Pyrrhonean tradition of "ethical" doubt. Touching here does not aim at a "reality check" or knowledge at all; it entirely concerns the position of the subject, his (or her) "moral and political education," the limits of good manners, taste, obscenity, and so on. This performance may therefore shed light even on the act performed by Jesus according to St. John's Gospel. Is the aim of touching in Doubting Thomas's case not also far more ethical than epistemological? Was Thomas's error not precisely his assumption that religious faith was a matter of knowledge? Did Jesus not shatter this assumption in a similarly shocking way, just as Valie Export called into question all assumptions about good manners, respect between genders, and respect between individual persons?

Can the whole "conversion" of St. Thomas not simply be described precisely by saying that Jesus prompted his transformation from a Cartesian sceptic into a Pyrrhonean one? Is the whole point of the biblical story not precisely that even the most certain knowledge does not help at all in matters of faith, since religion is not a cognitive, but an ethical issue? Thomas wants to replace doxa with reliable knowledge. Yet Jesus then provides him with reliable knowledge, but also with the insight that this knowledge is not of decisive help. He demonstrates to Thomas that even after having obtained reliable knowledge, the problem of doxa, in the sense of faith, persists. Jesus's action actually allows Thomas to replace one doxa (the opinion that knowledge helps) with another-a subjective commitment that, as it were, plays in a different register from objective knowledge. Just as Jesus is, in Caravaggio's ingenious depiction, actually the one who exerts the touch (by forcing Thomas to touch), he can also be seen as the actual sceptic in the scene, for it is Jesus who questions Thomas's assumption about the helpfulness of knowledge in religious matters. The 
"conversion" of St. Thomas that takes place in this scene can thus also be formulated as "Dear Thomas, I will show you which of us is the real sceptic."

Jesus's action thus provided "sceptical” Thomas not with knowledge, but actually with the most profound challenge to his ethical position. On the epistemological, Cartesian level of doubt, on the contrary, nothing has been clarified at all: since touching, as Descartes pointed out, does not escape the potential for illusion. If the apostles actually only dreamed of meeting Jesus, as St. Thomas may have suspected, why couldn't the impression of touching his wound also be merely a dream? If there was any efficiency to this action, it clearly did not consist in an epistemological gain of either knowledge or certainty. To frame it in Roland Barthes's terms, Jesus did not allow Thomas to verify an element of his studium, but rather confronted him with a punctum. He did not communicate with the sceptic on the level of expectations and willfully sought knowledge, but on the level of both the unexpected and the unwilling encounter. Instead of providing Thomas with evidence or proof, Jesus gave him something to think and to doubt. Just like a wise teacher of a Far Eastern religion, Jesus confronted the other with a small, enigmatic action that forced him to question his own assumptions; as Barthes would have called it, Jesus enacted a little "satori, the passage of a void." 51

\section{The Sceptical Touch of Art}

This is what aligns the action ascribed to Jesus with those of performance artists like Valie Export. It was probably Caravaggio's genius to single out this artistic dimension of Jesus's intervention-of Jesus the performance artist, as it were, the punctum in Caravaggio's depiction being precisely the strong hand of Jesus that forces Thomas's finger to do what one may expect, according to moral education and biblical studium: to get into the wound.

If there is a proper concise description of what performance does, as opposed to theatre, one can say that it does not represent matters, but presents them; or, in Ludwig Wittgenstein's terms, it does not say things, but shows them. ${ }^{52}$ Here, the terms used by J.L. Austin allow a kind of etymology or nominal explanation: performance is not "constative," but "performative."53 By letting Thomas touch the truth, Jesus showed him at the same time that the question of truth is completely irrelevant to what is at stake here-the issue of religious commitment. Thomas's "treatment" can thus easily be compared to certain actions in psychodrama where crucial situa-

51 Barthes, Camera Lucida, 49.

52 Ludwig Wittgenstein, Tractatus logico-philosophicus. Logisch-philosophische Abhandlung, 14 th ed. (Frankfurt am Main: Suhrkamp, 1979), sentences 4.022, 4.121, 5.62, and 6.522. Compare Barthes, Camera Lucida, 51: "What I can name cannot really prick me."

53 See J.L. Austin, How to Do Things with Words: The William James Lectures Delivered at Harvard University in 1955, ed. J.O. Urmson (Oxford: Clarendon Press, 1962). 
tions are not merely discussed, but enacted "live." For example, a patient who has always wanted to beat her stepfather is given a stick made of rubber foam (the socalled "Battuta") and is allowed to hit a person playing her stepfather's role. ${ }^{54}$ The key issue in this "wish-fulfilment" seems to be the fact that the person with the irresistible wish is thus brought to the point where the wish no longer protects her from encountering the question: "And what now?" In other words, the person has to face and live the situation after the resolution of her presumed life problem. In many cases, it turns out that this new situation is the real problem and that the formula "If only I had had the chance to..." only serves as a screen that permits one to avoid confronting life with all its small concerns. The "life problem" can thus be experienced as a clever solution to a failure to face the actual difficulties of life. In the same way, Thomas's wish, "If only I had the chance to touch Jesus's wounds in order to gain certain knowledge," is revealed in its function as a screen for the still-remaining problem of religious faith. Thomas's "epistemological" doubt serves as a comfortable screen against facing the ethical problem of religious life. The touch from the dramatic punctum provided by Jesus allows Thomas to question his defensive; that is, to doubt his defence made up of "epistemological" doubt.

Only the "lived" or "shown" experience of the performance, the satori or psychodramatic enactment, allows us to tackle the lived certainty of the other. Only in this way can a subject's comfort zone be touched. Against a communication on the "visual" level of the studium, where the subject willfully and wishfully sees itself, a communication on a different, haptic level takes place. If one felt entitled, due to Barthes's own various references to psychoanalytic theory, ${ }^{55}$ to render his account in Lacanian terms, one would have to state that the shift from studium to punctum is a shift from the "imaginary" to the "symbolic" axis of communication. It is precisely along this axis that a communication can take place in which a person reveals more than he or she knows. Whereas from the imaginary position, a person tells us what he knows, as well as what he wants to know and how he wants to see himself, from the symbolic position, the unconscious can speak and the actual condition of the subject can be revealed.

Barthes touches this point when he notes that on the level of the studium, he only encounters what the photographer wants to say. ${ }^{56}$ On the level of the punctum, however, the photograph says something else, something different or more than what they originally intended-and this allows the spectator to be "touched." Only along

54 For the methods of psychodramatic role-playing, see Lewis Yablonsky, Psychodrama: Resolving Emotional Problems through Role-Playing (New York: Basic Books, 1976).

55 For example, Barthes calls the punctum a "partial object” (Camera Lucida, 43).

56 "To recognize the studium is inevitably to encounter the photographer's intentions, to enter in harmony with them, to approve or disapprove of them, but always to understand them" (Camera Lucida, 27 f.). For a most precise account of the relation between Barthes's concept of the punctum and Lacan's notions of the "Real," "tyche," the "gaze," etc., see Jennifer Friedlander, Feminine Look: Sexuation, Spectatorship, Subversion (Albany, NY: SUNY Press, 2008), $11 \mathrm{ff}$. 
this axis of communication can a shift of opinion, or doxa, actually be effected -just as in the case of St. Thomas. This is of particular importance when it comes to the issue of the political efficiency of art. Barthes is perfectly clear on this point: on the level of the studium, a photograph cannot make its spectators critical or sceptical, for it can only convince those who are already convinced: "No critique except among those who are already capable of criticism." 57

On the level of the studium, art always functions only as an affirmative, assuring force. It confirms what a subject already wants to see in herself and reinforces the opinions a subject already finds suitable to himself. On the level of the studium, art cannot do anything else, to put it in biblical terms, than to preach to the already converted (like the non-doubting apostles). Only on the level of the punctum can someone actually be touched in such a way that a sceptical, "pensive" stance can be taken; that some flexibility of the subject position is induced so that a different opinion can be adopted.

Barthes's finding is of particular relevance today, at a moment when art is hoping to become more "political" by increasingly promoting social and political issues at the level of the studium, thus investing most of its effort in its content while neglecting issues of form; namely, when it concerns itself only with what to communicate instead of how to communicate with the spectator. This tendency is recently often reinforced by art's becoming academic and by the predominant contemporary understanding of the notion of "artistic research." In many cases, artistic research is understood as scientific research undertaken by artists that may help their work to become more scholarly and richer in well-founded scientific content. ${ }^{58}$ Yet again, such an understanding only contributes to the studium. It contributes, as Barthes would put it, to what one can name, but not to by what one can be pricked..$^{59}$

A cleverer-and more epistemologically accurate-understanding would instead describe artistic research as what leads to the result's being art and not science, or investigative journalism, or anything else that belongs to the field of knowledge, information, or content. Such an understanding that connects artistic research to the specificity of artistic practice would shift the focus onto the specific ways in which art can speak: its form. With a stronger focus on this aspect, a researching art could refine its methods of how to reach other people than the already convinced; of how to make spectators pensive and sceptical, and how to touch and tackle them in their most treasured opinions. For only by telling what it does not know

57 Barthes, Camera Lucida, 36.

58 The misunderstanding here is obvious: the character of research is judged by who undertakes it, not by what its method is. Yet when artists conduct scientific research, this is just as "artistic" as music can be said to be "dental" due to the fact that dentists play the cello. The artistic research is not the scientific part, i.e., the raw material that is used for artistic production, but the very methodical process by which this (or any other) raw material is transformed into an art product.

59 Barthes, Camera Lucida, 51. 
can art put the observers' fingers into a wound: by producing a "passage of the void," it ceases to complete their knowledge, but starts to supplement their beliefs.

\section{Bibliography}

Althusser, Louis. L'avenir dure longtemps, suivi de Les faits. Edited by Olivier Corpet and Yann Moulier Boutang. 2nd augmented ed. Paris: STOCK/IMEC, 1994.

Althusser, Louis. On Ideology. Translated by Ben Brewster. New ed. New York: Verso, 2008.

Aristotle. De anima. Translated by R.D. Hicks. Cambridge: Cambridge University Press, 1907.

Aurelius, Marcus. Meditations. Accessed 19/09/2018. http://www.gutenberg.org/files/2680/2680-h/2680-h.htm\#link2H_4_0243.

Aurelius, Marcus. Selbstbetrachtungen. Translated by Wilhelm Capelle. Stuttgart: Kröner, 1948.

Austin, J.L. How to Do Things with Words: The William James Lectures Delivered at Harvard University in 1955. Edited by J.O. Urmson. Oxford: Clarendon Press, 1962.

Barthes, Roland. Camera Lucida: Reflections on Photography. Translated by Richard Howard. New York: The Noonday Press, 1988.

Barthes, Roland. La chambre claire: Note sur la photographie. Paris: Cahiers du cinéma/Gallimard/Seuil, 1996.

Benjamin, Walter. “Über den Begriff der Geschichte.” In Gesammelte Schriften, Bd. 1/2: Abhandlungen, edited by Rolf Tiedemann and Hermann Schweppenhaüser, 691-704. Frankurt am Main: Suhrkamp, 1980.

Diderot, Denis. "The Letter on the Blind." In Diderot's Early Philosophical Works, edited and translated by Margaret Jourdain, 68-141. Chicago and London: The Open Court Publishing Company, 1916.

Dolar, Mladen. "Officers, Maids, and Chimneysweepers." In Sex and Nothing: Bridges from Psychoanalysis to Philosophy, edited by Alejandro Cerda-Rueda, 19-36. London: Karnac, 2016.

Dolar, Mladen. "Tyche, Clinamen, Den." Continental Philosophy Review 46, no. 2 (2013): 223-39.

Epictetus. The Enchiridion. Translated by Elizabeth Carter. Accessed 19/09/2018. http://classics. mit.edu/Epictetus/epicench.html.

Epictetus. Handbüchlein der Moral: Griechisch/Deutsch. Edited and translated by Kurt Steinmann. Stuttgart: Reclam, 2004.

Epicurus. Briefe, Sprüche, Werkfragmente: Griechisch/Deutsch. Edited and translated by Hans-Wolfgang Krautz. Stuttgart: Reclam, 2005.

Evans, Dylan. An Introductory Dictionary of Lacanian Psychoanalysis. Reprint ed. New York: Routledge, 1997.

Export, Valie, and Peter Weibel. “Aus der Mappe der Hundigkeit.” Accessed 31/08/2018. http:// peter-weibel.at/index.php?option=com_content\&view=article\&id=27\%3Aaus-der-mappe-derhundigkeit-1968\&catid=2\%3Amixed-media\&lang=de\&ltemid=11 and http://foundation.gen erali.at/sammlung/artist/export-valiepeter-weibel/artwork/aus-der-mappe-der-hundigkeit-5. html\#.W4qV8i35zNM.

Freud, Sigmund. "Beyond the Pleasure Principle." In The Standard Edition of the Complete Psychological Works of Sigmund Freud, Volume 18 (1920-1922): Beyond the Pleasure Principle, Group Psychology and Other Works, edited by James Strachey et al., 7-64. London: The Hogarth Press, 1955.

Freud, Sigmund. "Civilization and Its Discontents." In The Standard Edition of the Complete Psychological Works of Sigmund Freud, Volume 21 (1927-1931): The Future of an Illusion, Civilization and Its Discontents and Other Works, edited by James Strachey et al., 59-145. London: The Hogarth Press, 1961. 
Freud, Sigmund. "Fetishism." In The Standard Edition of the Complete Psychological Works of Sigmund Freud, Volume 21 (1927-1931): The Future of an Illusion, Civilization and Its Discontents and Other Works, edited by James Strachey et al., 147-57. London: The Hogarth Press, 1961.

Freud, Sigmund. "An Outline of Psychoanalysis." In The Standard Edition of the Complete Psychological Works of Sigmund Freud, Volume 23 (1937-1939): Moses and Monotheism, An Outline of Psychoanalysis and Other Works, edited by James Strachey et al., 23-207. London: The Hogarth Press, 1964.

Freud, Sigmund. "Three Essays on the Theory of Sexuality." In The Standard Edition of the Complete Psychological Works of Sigmund Freud, Volume 7 (1901-1905): A Case of Hysteria, Three Essays on Sexuality and Other Works, edited by James Strachey et al., 125-245. London: The Hogarth Press, 1953.

Freud, Sigmund. "The Uncanny." In The Standard Edition of the Complete Psychological Works of Sigmund Freud, Volume 17 (1917-1919): An Infantile Neurosis and Other Works, edited by James Strachey et al., 219-56. London: The Hogarth Press, 1955.

Friedlander, Jennifer. Feminine Look: Sexuation, Spectatorship, Subversion. Albany, NY: SUNY Press, 2008.

Heine, Heinrich. Ideen. Das Buch Le Grand. Edited by Dierk Möller. Stuttgart: Reclam, 1972. Lacan, Jacques. Écrits: A Selection. Translated by Alan Sheridan. London: Tavistock, 1977.

Lacan, Jacques. Le séminaire, livre X: L'angoisse, 1962-63. Edited by Jacques-Alain Miller. Paris: Seuil, 2004.

Laplanche, Jean. Le primat de l'autre en psychanalyse: Travaux 1967-1992. Paris: Flammarion, 1997.

Luck, Georg, ed. and trans. Die Weisheit der Hunde: Texte der antiken Kyniker in deutscher Übersetzung mit Erläuterungen. Stuttgart: Kröner, 1997.

Lucretius. De rerum natura libri sex. Accessed: 09/02/2020. http://www.thelatinlibrary.com/lucretius.html.

Marcuse, Ludwig. Obszön: Geschichte einer Entrüstung. Zürich: Diogenes, 1984.

Moser, Jakob. "Manifest gegen die Evidenz. Tastsinn und Gewissheit bei Lukrez." In Auf die Wirklichkeit zeigen. Zum Problem der Evidenz in den Kulturwissenschaften. Ein Reader, edited by Helmut Lethen, Ludwig Jäger, and Albrecht Koschorke, 85-105. Frankfurt: Campus, 2015.

Nietzsche, Friedrich. Beyond Good and Evil: Prelude to a Philosophy of the Future. Edited by Rolf-Peter Horstmann and Judith Norman. Translated by Judith Norman. Cambridge: Cambridge University Press, 2002.

Pfaller, Robert. "Materialism's Comedy." Bedeutung 1 (2008): 20-28.

Pfaller, Robert. The Pleasure Principle in Culture: Illusions without Owners. Translated by Lisa Rosenblatt with Charlotte Eckler and Camilla Nielsen. London: Verso, 2014.

Schmidt, Ernst A. Clinamen: Eine Studie zum dynamischen Atomismus der Antike. Heidelberg: Universitätsverlag Winter, 2007.

Wagner, Anselm. "Der Künstler als Hund. Kynische Strategien der Körperkunst." Noema art journal 43 (1996): 52-60.

Wallace, David Foster. "This Is Water." Commencement speech delivered at Kenyon College in 2005. Accessed 18/09/2018. https://www.youtube.com/watch?v=8CrOL-ydFMI.

Weber, Ernst Heinrich. Tastsinn und Gemeingefühl. Edited by Ewald Hering. Leipzig: Wilhelm Engelmann, 1905.

Wilder, Billy. "The Lubitsch Touch." Presented at the AFI Harold Lloyd Master Seminar in 1976. Accessed 20/08/2018. https://www.youtube.com/watch?v=7jOVRKzwURY.

Wittgenstein, Ludwig. Tractatus logico-philosophicus. Logisch-philosophische Abhandlung. 14th ed. Frankfurt am Main: Suhrkamp, 1979. 
Yablonsky, Lewis. Psychodrama: Resolving Emotional Problems through Role-Playing. New York: Basic Books, 1976.

Zupančič, Alenka. The Odd One In: On Comedy. Cambridge, MA: MIT Press, 2008. 